\title{
Agro-Allied Small and Medium Enterprises and the Economy of Kogi State, Nigeria
}

\author{
Durotimi Amos Dada ${ }^{1 *}$, Unekwu Cynthia Alogwuja $^{2}$, \\ Mayowa Olumoyegun ${ }^{2}$
}

\footnotetext{
${ }^{1}$ Department of Business Administration, Achievers University, Owo, KM 1, Idasen/Uteh Road, Owo, Ondo State, Nigeria.

2 Department of Business Administration, Kogi State University, PMB 1008, Anyigba, Nigeria. e-mail: durotimiamosdada01@gmail.com
}

DOI: 10.51865/EITC.2021.04.06

\begin{abstract}
This paper focused on Agro-allied Small and Medium Enterprises and the economy of Kogi State, Nigeria. The specific aims were to ascertain the effect of agriculture on the GDP of Nigeria, and examine how entrepreneurial activities of Agro-allied SMEs affect job creation in Kogi State. The researchers employed survey research design; using purposive sampling where 120 'agripreneurs' (farmers who are entrepreneurs) were selected. The study covered three senatorial districts. Both descriptive and inferential analytical techniques (Multiple Regression Model) were applied for data analysis. Finding showed that the effects of entrepreneurial activities of Agro-allied SMEs on job creation in Kogi State are weak. Furthermore, finding showed that Contribution to Agricultural Sector (CTAS) has a positive relationship with Gross Domestic Product in Nigeria. The study concluded that empowerment of Agroallied SMEs will culminate into reduced unemployment rate. The study recommended that government should make long-term investment in the agriculture sector to increase positive impact on the GDP of Nigeria, and that the economic stakeholders should strategically empower, promote and protect the entrepreneurial activities of Agro-allied SMEs to take advantage of increased job creation in Kogi State.
\end{abstract}

Keywords: agri-entrepreneurial activities; contribution to agricultural sector; job creation; unemployment rate; investment.

JEL Classification: L32; O13; Q13.

\section{Introduction}

Agriculture has been spinal to the development of other sectors in Nigeria. According to Uzoigwe (2007), agriculture is the key sector in Nigeria. The oil sector has generated huge revenue for Nigeria, but her rate of unemployment and poverty keeps increasing annually. The government intervened and supported varying entrepreneurial programmes to reduce unemployment and poverty rate in Nigeria. The revenue from crude oil export would have been used to support development in the agricultural sector. Oluwagbemiga (2017) expressed that the massive profits from crude oil exports were enough to tempt the Nigerian government to ignore

${ }^{*}$ Corresponding author 
other economic sectors. Today the contribution of oil industry has dropped seriously in Nigeria. Varrella (2021a) expressed that the oil industry contributed 5.9 percent of total real GDP between October and December 2020, a decline of approximately three percentage points from the previous quarter.

The contribution of agriculture to the GDP in Nigeria has been incredible recently. Central Bank of Nigeria (2016) noted that agricultural sector's contribution to the GDP in Nigeria is 24.18 percent. Varrella (2021b) noted that agriculture contributed 26.95 percent of total GDP between October and December 2020. It has two major components; namely, food production and export commodities, and a more productive sector that would boost growth (World Bank, 2004: 211). Importantly, agriculture avails industries with raw materials for effective operations. Onwualu (2009) posited that the materials are important component of every enterprise in Nigeria. This implies that the support for agricultural sector will result to improved development for Agroallied Small and Medium Enterprises (SMEs) in Kogi State.

The activities of Agro-allied SMEs have been contributory to the level that the economy of Kogi State has attained today. This could be viewed from its contribution to the GDP. SMEs account for 48 percent of the country's GDP, 96 percent of businesses, and 84 percent of employment (PwC Nigeria, 2021). They are also known for 'the generation of employment opportunities, stimulation of indigenous entrepreneurship, and facilitation of effective mobilisation of local resources' (Adeyipo, 2019). One will argue that SMEs rely on agricultural products (which aid conversion into several goods). For instance, many SMEs are into food processing (using oranges, cashew, cassava, papaw, coffee and so on).

Agro-allied SMEs drive local innovation in the economy through effective and efficient utilization of agro-allied raw materials. Cashew nut is an important raw material used by many SMEs. Deckers, Cundall, Shomari and Bassi (2001) expressed that cashew nuts are processed into raw materials usable for the production of other goods. Unfortunately, cashew nut is largely exported in Kogi State, with little or no consideration for Agro-allied SMEs. More than $80 \%$ of raw cashew nuts are still being exported, especially to India, Vietnam and Indonesia. Exporting crude cashew nut may be too expensive for Kogi State. For example, cashew made raw materials is very expensive because exported cashew nuts are reprocessed into raw materials for industrial use and then imported into the country (with the inclusion of importation duties and the interplay of economic factors in the suppliers' country). This may be attached to the slow pace of Agro-allied SMEs' development as noted by Adeyipo (2019). Thus, this study is narrowed down to Agro-allied SMEs making use of cashew nuts.

Agro-allied SMEs that are victims of sluggish growth and development may not be able to contribute to employment generation in Kogi State. There is no doubt that unemployment rate in Kogi State can be reduced by growing and developing Agro-allied SMEs. Unemployment is a dangerous economic challenge that may bring down the later generation. Ajufo (2013) expressed that its consequences have indescribable effect on the economic and the social wellbeing.

The specific objectives of this study are to:

i. Ascertain the effect of agriculture on the GDP of Nigeria.

ii. Examine the effects of entrepreneurial activities of Agro-allied SMEs on job creation in Kogi State.

\section{Literature Review}

\section{Conceptual review}

Agro-allied is the industry that is closely related to cultivating soils, growing plants, and producing crops and cannot be successful without raw materials. Agro-allied industries are 
industries which depend on agriculture for their raw materials so as to operate successfully in the production of finished goods that are useful to livestock and humans. Ajila (2014) explained that the agro-allied industries bring about diversification and commercialization of agriculture and also enhance the income of farmers and create food surpluses. Its development could help to stabilize and make agriculture more lucrative, thereby creating employment opportunities both at the production and marketing stages (Jelilo and Bahago, 2017; Oraka, Ocholi and Ater, 2017: 157).

Agro-allied SMEs have made colossal Contribution to Agricultural Sector (CAS). This CAS implies substantial resource transfer for productive means. The CAS also encompasses innovativeness and development of many kinds relative to technology transfer and adoption. Agro-allied SMEs are enterprises with Annual Debit Turnover ofN5 million to 500 million and with Staff Strength of 300 (CBN Annual Report 2016). Their scope and sizes are determined by the volume of their asset, staff and finance. Agro-allied SMEs' development therefore implies progressive change in their size and scope considering increased asset, staff and finance. The development of Agro-allied SMEs may be facilitated through promotion and support from all economic stakeholders.

Agro-allied SMEs are paraphernalia for economic growth. They are noted for 'the generation of employment opportunities, stimulation of indigenous entrepreneurship, and facilitation of effective mobilisation of agricultural resources' (Adeyipo, 2019). One will argue that they rely on agricultural raw materials (which aid conversion into several products). For instance, many SMEs are into food processing (using oranges, cashew, cassava, papaw, coffee and so on). Agro-allied SMEs drive local innovation in the economy through effective and efficient utilization of agricultural raw materials. Deckers et al. (2001) noted that some firms processed cashew nuts into kernel that is very valuable, export product for confectionary, ingredients for fruit paste, canned fruits, cashew apple and fruit juice. Exporting crude cashew nut may be too expensive on the economy of Kogi State. Exported crude cashew nuts are reprocessed for industrial use and then imported into the country at a high cost. This may be attached to the slow pace of SMEs development as noted by Adeyipo (2019).

Nigeria is $4^{\text {th }}$ largest producer of cashew nuts in Africa and $7^{\text {th }}$ in the world. Current (ACA) reports ranks Nigeria as the world second largest producer of cashew nut with an annual output estimated at 960,000 tons with global demand for commodity increasing 53\% since 2010, it has the potential of being a major foreign exchange earner. The uniqueness of its employment generation and income empowerment capacity becomes more profound when viewed against the fact that over $70 \%$ of the workforce in cashew business is women, mainly working in Cashew processing. Its role in income generation, poverty eradication and life bettering economic development of Kogi state cannot be over-emphasized.

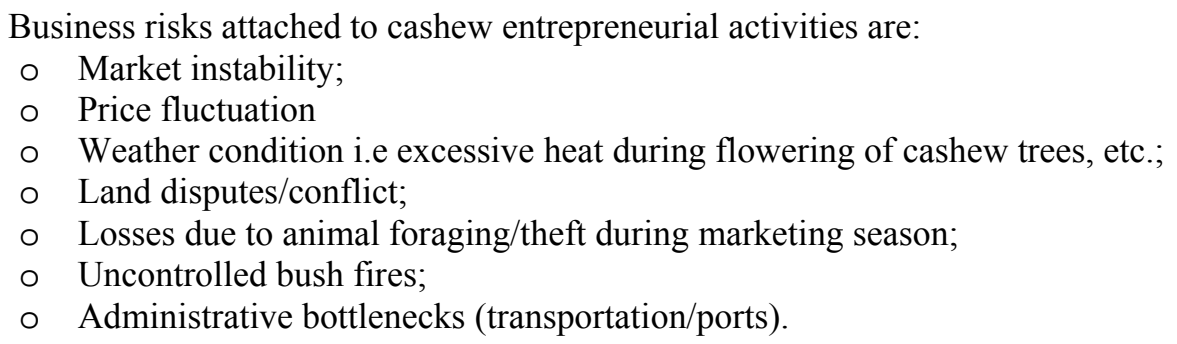

\section{Industrialization/agricultural policy and incentives for SMEs}

According to the National Planning Commission (2004:78), the "overriding objective of the industrial policy being pursued by the Nigerian government is to accelerate the pace of industrial development by radically increasing value-adding at every stage of the value-chain". As earlier noted SMEs are the life wire of the economy of Kogi State. This may be 
incontrovertible because small businesses exist even in the remote areas of the state. In fact, the number of households whose incomes are mainly from small scale farming businesses is high. Thus, it expected that increase in the number of healthy SMEs will lead to increase in employment generation and wealth creation. It is important to provide a platform for increasing productivity related to import replacement and exports expansion; enhancing foreign exchange earnings; generating employment; and raising per capita income, which increases per capita consumption (Jelilo and Bahago, 2017).

Sessi (1999) cited in Carré and Levratto (2009) expressed those policies promoting SMEs are integrated into policy frameworks which concern other kinds of businesses, and moreover include measures that may not concern SMEs all. Promoting SMEs is the key to their development. Such promotion must include protecting the SMEs jealously since they are cardinal to the economic development. There is certainly a set of general policies on tax systems (gradual reduction of the tax rate on enterprise owners/farmers) and labour law (Carré and Levratto, 2009). Past governments initiated industrial policies (such as Structural Adjustment Policy, Trade and Financial Liberalization Policy, etc.). Uzoigwe (2007) found that the structural adjustment programme had positive impact on the agricultural and manufacturing production. Other policy areas and programmes (such as the Community Bank, Directorate for Food, Road and Rural Infrastructure (DFRRI), the National Directorate for Employment (NDE), the Peoples Bank, the Better Life for Rural Women, Family Support Programmes, Family Economic Advancement Programme (FEAP), the Open Apprenticeship Scheme (OAS)) were aimed at addressing unemployment, lack of access to credit, and the rural and gender dimensions of poverty. The policies are aimed at simplifying the business environment (Carré and Levratto, 2009), but it is clear today that the SME sector still witness setback. Though, the government is utilizing various incentive packages to encourage investment in the industrial sector of the economy. The incentives take the form of fiscal policy (such as tax deduction and allowances). In the case of Kogi State, the following incentives may be provided to initiate the development of SMEs including the small scale agro-allied enterprises:

o Tax Holiday: There is an observed overload of taxes which has caused entropy or dwindling profit for SMEs including the small scale agro-allied enterprises. By the size and capacity of SMEs, it will be dangerous to impose huge tax on them. Exempting them from profit tax payment for a particular period (from the start-up time) will contribute to their development. Importantly, such profit may be retained in business for expansion rather than often look elsewhere for expensive fund to keep the business alive. For existing SMEs (particularly the ones with outstanding performance), policy should be formulated to motivate the export of a reasonable percentage of their products.

o Guaranteed Investment and Protection: The government should ensure that investors have much confidence regarding their investment. No pressure must be mounted unduly on the investors to oblige them under duress to do anything apart from their corporate social responsibility (which is subject to the management discretion and resources). A foreign investor should be allowed to transfer funds unconditionally through authorized dealer in freely convertible currency. The government must ensure the protection of life and properties of investors (both foreign and national investors).

o Direct Involvement of Government: The government can manipulate the potentials of agriculture and SME sector in Kogi State through unstructured movement of monitoring teams (that is, an ad-hoc Committee should established- a number of teams should be established to pay uninformed visits to business owners.

o Kogi State Agro-Allied Research Institute (KSARI): A research institute (KSARI as suggested) should be established with a designed framework. The institute should partner with the higher institutions in Kogi State. The institute must operate in partnership with all agro-allied industries. The institute may research into the use of domestic agricultural raw materials and the usage of machinery and equipment. The institute should align with the 
Federal Institute of Industrial Research (FIIRO), Oshodi, and the Product Development Agency (PRODA).

- Access to Land: An incentive policy also guarantees that any enterprises incorporated in Nigeria be allowed access to land in the state of the federation, for industrial purposes (Essays, 2018). Industrial concerns are required to abide by the regulations on the use of land for industrial purposes and with environmental regulations (Essays, 2018).

\section{Methodology}

The study was qualitative in nature. Thus, primary data as well as secondary data was employed. The researchers adopted survey research design; this involves the survey of respondents to acquire first hand data for the study. Also the researchers adopted purposive sampling where 120 agripreneurs (farmers who are entrepreneurs) were selected. The study covered three senatorial districts. These are the major ethnic division in the State. A wellstructured questionnaire was considered majorly as the most appropriate data collection instruments for this study. A pilot study was conducted to test-run the validity of the study and to detect flaws in the data collection process. To establish the instrument's reliability, the Cronbach Coefficient alpha $(\alpha)$ was used.

Table 1. Units of measurement

\begin{tabular}{|l|l|c|c|}
\hline S/N & \multicolumn{1}{|c|}{ Variables } & Units & Results \\
\hline 1 & Job creation & 2 & 0.780 \\
\hline 2 & Market instability & 2 & 0.769 \\
\hline 3 & Price fluctuation & 2 & 0.851 \\
\hline 4 & Weather condition & 2 & 0.934 \\
\hline 5 & Land disputes/conflict & 2 & 0.901 \\
\hline 6 & Losses due to animal foraging/theft during marketing season & 2 & 0.944 \\
\hline 7 & Uncontrolled bush fires & 2 & 0.812 \\
\hline 8 & Administrative Bottlenecks (transportation/ ports) & 2 & 0.830 \\
\hline
\end{tabular}

Source: Field survey (2021).

Based on the critical point of 0.70 by Zikmund et al. (2010), the results show high reliability for the units of measurement (Table 1). The study analysed data using both descriptive and inferential analytical techniques. For the analyses, 'Multiple Regression Model' was applied.

Where:

$$
J C N=a+\beta_{1} E A S_{1}+e
$$

$\mathrm{JCN}=$ Dependent variable (implies job creation);

$\mathrm{a}=$ constant;

EAS $_{1}=$ the independent variable (Entrepreneurial Activities of Agro-allied SMEs);

$\beta_{1}=$ regression coefficient that determines the contribution of the independent variable;

$\mathrm{e}=$ Stochastic term.

Also regression model would be used to examine the nexus between agricultural sector contribution and economic growth (measured by gross domestic product) in Nigeria. The functional form of the relationship is provided in equation (2):

Where:

$$
Y i t=\beta_{i t}+\beta_{1} X_{i t}+\varepsilon_{t}
$$

$\mathrm{Y}_{\mathrm{it}}=$ dependent variable;

$\mathrm{X}_{\mathrm{it}}=$ vector of Independent variable;

$\beta_{\mathrm{i}}=$ unobserved factors;

$\varepsilon_{\mathrm{t}}=$ the error term. 
The model was modified to suit the best purpose of this research as shown in equation (3):

$$
G D P_{i t}=\mathrm{f}\left(C T A S_{i t}\right)
$$

This model was further transformed into an econometric model as equation (4):

$$
G D P_{i t}=\propto_{0}+\beta_{1} C T A S_{i t}+\varepsilon_{i t}
$$

Where:

$\alpha=$ constant represent value of GDP when all others explanatory variables are held constant;

$\beta_{1}=$ Coefficient of the explanatory variable;

$\varepsilon_{\mathrm{it}}=$ error term;

$\mathrm{GDP}_{\mathrm{it}}=$ Gross Domestic Product as dependent variable;

CTASit $=$ Contribution to Agricultural Sector.

\section{Results and Discussion}

Table 2 indicates that market instability $($ mean $=1.0917$; standard deviation $=0.28976)$, price fluctuation $($ mean $=1.0750$; standard deviation $=0.26450)$, weather condition $($ mean $=1.1000$; standard deviation $=0.26450)$, land disputes/conflict $($ mean $=1.1833$; standard deviation $=$ 0.38856 ), losses due to animal foraging/theft during marketing season (mean $=1.2667$; standard deviation $=0.44407)$, uncontrolled bush fires $($ mean $=1.2417$; standard deviation $=0.42989)$ and administrative bottlenecks (mean $=1.1917$; standard deviation $=0.39526$ ) are basic business risks attached to agri-entrepreneurial activities. On the scale of 1-10, losses due to animal foraging/theft during marketing season seems to be the most severe. Also uncontrolled bush fire is another severe risks attached to agri-entrepreneurial activities in Kogi State. The standard deviation (0.44407) for the data supplied for 'losses due to animal foraging/theft during marketing season' shows high divergence from the mean. This also applied to the data supplied for 'uncontrolled bush fires' given the standard deviation of 0.42989. Across other variables, the divergences appear to be determined by the mean scores.

The Table 2 also shows Kurtosis statistics for market instability (6.320), price fluctuation (8.828), weather condition (5.382), land disputes/conflict (.760), losses due to animal foraging/theft during marketing season (-.873), uncontrolled bush fires (-.515) and administrative bottlenecks (.526). The assumption of asymmetric distribution was not met in the data provided for 'losses due to animal foraging/theft during marketing season and, uncontrolled bush fires'. For other variables, the data conformed to the assumption of asymmetric distribution.

Table 2. Descriptive statistics of risks attached to agri-entrepreneurial activities

\begin{tabular}{lcccc}
\hline & Mean & Std. Deviation & \multicolumn{2}{c}{ Kurtosis } \\
\cline { 2 - 5 } & Statistic & Statistic & Statistic & Std. Error \\
Market instability & 1.0917 & .28976 & 6.320 & .438 \\
Price fluctuation & 1.0750 & .26450 & 8.828 & .438 \\
Weather condition & 1.1000 & .30126 & 5.382 & .438 \\
Land disputes/conflict & 1.1833 & .38856 & .760 & .438 \\
$\begin{array}{l}\text { Losses due to animal } \\
\text { foraging/theft during }\end{array}$ & 1.2667 & .44407 & -.873 & .438 \\
marketing season & 1.2417 & .42989 & -.515 & .438 \\
Uncontrolled bush fires & 1.1917 & .39526 & .526 & .438 \\
$\begin{array}{l}\text { Administrative Bottlenecks } \\
\text { (transportation/ ports) }\end{array}$ & & & & \\
\hline
\end{tabular}

Source: Field survey (2021). 
Table 3 shows that $45 \%$ change in job creation is explained by the entrepreneurial activities of Agro-allied SMEs in Kogi State. The remaining 55\% unaccounted implies that there are many other variables that can predict change in job creation in Kogi State. The result shows that the effects of entrepreneurial activities of Agro-allied SMEs on job creation in Kogi State are weak.

Table 3. Model summary on entrepreneurial activities of Agro-allied SMEs and job creation

\begin{tabular}{ccccc}
\hline Model & R & R Square & Adjusted R Square & $\begin{array}{c}\text { Std. Error of the } \\
\text { Estimate }\end{array}$ \\
\hline 1 & $.671^{\mathrm{a}}$ & .450 & .445 & .91881 \\
\hline
\end{tabular}

a. Predictors: (Constant), Entrepreneurial activities of Agro-allied SMEs

Source: Field survey (2021).

Table 4 shows that a positive linear relationship exists between entrepreneurial activities of Agro-allied SMEs and job creation in Kogi State (give that $\beta=0.694$; $\mathrm{p}$-valu $\mathrm{e}=0.01$ ). That is $69.4 \%$ increase in the entrepreneurial activities of Agro-allied SMEs will lead to proportional increase in job creation in Kogi State. The p-value shows that the linear relationship between entrepreneurial activities of Agro-allied SMEs and job creation in Kogi State is a significant one.

Table 4.Coefficients on entrepreneurial activities of Agro-allied SMEs and job creation

\begin{tabular}{llccccc}
\hline Model & \multicolumn{2}{c}{$\begin{array}{c}\text { Unstandardized } \\
\text { Coefficients }\end{array}$} & $\begin{array}{c}\text { Standardized } \\
\text { Coefficients }\end{array}$ & & T & Sig. \\
\cline { 3 - 4 } & & B & Std. Error & Beta & & \\
1 & 1.272 & .144 & & 8.857 & .000 \\
& Entrepreneurial activities of & .694 & .071 & .671 & 9.828 & .000 \\
Agro-allied SMEs & & & & & \\
\hline
\end{tabular}

a. Dependent Variable: Job creation

Source: Field survey (2021).

Table 5 above revealed the overall aggregate effects of agricultural sector on gross domestic product included in the model are able to explain $77.89 \%$, which is indicated by the Adjusted $\mathrm{R}^{2}$ from the regression result, while the remaining $22.11 \%$ are controlled by other factors that are not included in the model. The F-statistics of 32.7 and significant at 0.0000 shows that the model is fitted for the study and therefore provides substantial evidence that agricultural sector has effect on the gross domestic product.

Also, the result in table 5 shows that agricultural sector (CTAS) has a positive relationship with gross domestic product in Nigeria. This is based on coefficient value of 188.9976. This implies that a $1 \%$ increase in CTAS will lead to an increase in gross domestic product (GDP) by $188.9976 \%$. The p-value of 0.0004 which is less than the conventional alpha value of 0.05 shows this is highly significant. This means that the null hypothesis that state that agricultural sector do not contribute to the economic growth in Nigeria was rejected. The rejection of the null hypothesis implies that Agricultural sector have any significant effect on economic growth in Nigeria.

Also, the regression model was subjected to series of post-estimation tests such as multicollinearity, normality and hetero-skedasticity tests (see appendix 1) to determine the validity of the model estimation. The study utilized Variance inflation Factor (VIF) to test for multicollinearity (Kothari \& Garg, 2014). A VIF figure above $\geq 10$ shows serious multicollinearity (Kothari \& Garg, 2014). The VIF is found to be consistently smaller than 10, indicating the absence of multicollinearity (appendix 2) as suggested by Tobachnick and Fidell (2013) and Kothari and Garg (2014). The low mean VIF is also a pointer to the mild correlation 
among the regressors. This shows the appropriateness and fitness of the explanatory variable as used in the model.

Result of normality test conducted as shown (see Appendix 3) indicate Jarque-Bera value of 1.09 with its corresponding probability value of 0.5792 . Thus, it reveals that the study's data are normally distributed. A test of hetero-skedasticity is conducted to ascertain the homo-skedastic or hetero-skedatic nature of data for the study. Hetero-skedasticity refers to a circumstance in which the variability of a variable is unequal across the range of values of a second variable that predicts it. The summary result in table (see Appendix 2) shows the F-statistics value of 1.73 with a corresponding probability value of 0.224 , which is greater than the $5 \%$ level of significance. Hence, the study fails to reject the hypothesis of no homo-skedasticity. The results simply indicate that the data for analysis are homo-skedastic.

Table 5. Regression result on agriculture and GDP of Nigeria

\begin{tabular}{llccc}
\hline \hline \multicolumn{1}{c}{ Variable } & Coefficient & Std. Error & t-Statistic & Prob. \\
\hline \multicolumn{1}{c}{ C } & 305223.0 & 17454.66 & 17.48663 & 0.0000 \\
\multicolumn{1}{c}{ CTAS } & 188.9976 & 33.04702 & 5.719050 & 0.0004 \\
\hline \hline & & & \\
R-squared & 0.803476 & Mean dependent var & 396076.1 \\
Adjusted R-squared & 0.778911 & S.D. dependent var & 48636.56 \\
S.E. of regression & 22868.97 & Akaike info criterion & 23.08981 \\
Sum squared resid & $4.18 \mathrm{E}+09$ & Schwarz criterion & 23.15032 \\
Log likelihood & -113.4490 & Hannan-Quinn criter. & 23.02342 \\
F-statistic & 32.70753 & Durbin-Watson stat & 1.176809 \\
Prob(F-statistic) & 0.000445 & & \\
\hline \hline
\end{tabular}

Source: Field survey (2021).

\section{Conclusions and Recommendations}

Agro-allied SMEs have great connection with the well-being of the Nigerian economy. There is empirical evidence that the entrepreneurial activities of Agro-allied SMEs have contributed to job creation. This implies that empowerment of Agro-allied SMEs will culminate into reduced unemployment rate. This is because the empowerment will translate to increased volume of the entrepreneurial activities of Agro-allied SMEs. Logically, Agro-allied SMEs are bound to create more jobs given increased volume of their entrepreneurial activities. Also the aggregate effect of agricultural sector on GDP is interesting. Scientific verification revealed that the GDP of Nigeria heavily rely on the agricultural sector. This is likely to be made possible by the collaboration between agricultural sector and SME sector in Nigeria.

Some risks are attached to agri-entrepreneurial activities in Kogi State. This study identified market instability, price fluctuation, weather condition, land disputes/conflict, losses due to animal foraging/theft during marketing season, uncontrolled bush fires and administrative bottlenecks. It was discovered that uncontrolled bush fire and losses due to animal foraging/theft during marketing season are the most severe risks that are attached to agri-entrepreneurial activities in Kogi State.

The study recommends that:

o The government should make long-term investment in the agriculture sector to increase positive impact on the GDP of Nigeria. 
o Economic stakeholders should strategically empower, promote and protect the entrepreneurial activities of Agro-allied SMEs to take advantage of increased job creation in Kogi State.

\section{References}

1. Adeyipo, A., 2019. SMEs engine room of economic development, says CWG chief. Small Business and Entrepreneurship. The Nation. Available through: https://thenationonlineng.net/smes-engine-room-ofeconomic-development-says-cwg-chief/.

2. Ajila, A., 2014. Agro-allied industries - Bedrock of the Nation's economic revival. In: E.O. Oraka, A. Ocholi and P.I. Ater (eds.). Social Impact of Agro-Allied Industries on the Rural Dwellers in Benue State, Nigeria. Journal of Agribusiness and Rural Development. 43(1): 157-162. http://dx.doi.org/10.17306/J.JARD.2017.00272.

3. Carré, D. and Levratto, N., 2009. Industrial Policy and SMEs: A New Policy and New Tools? Revue d'économieindustrielle, 126 (2): 9-30. Available through: https://www.cairn.info/revue-revue-deconomie-industrielle-2009-2-page-9.htm.

4. Central Bank of Nigeria, 2016. Contribution of the agricultural sector to Nigeria's Gross Domestic Product, GDP. In: E.O. Oraka, A. Ocholi and P.I. Ater (eds). Social Impact of Agro-Allied Industries on the Rural Dwellers in Benue State, Nigeria. Journal of Agribusiness and Rural Development. 43(1): 157-162. Available through: http://dx.doi.org/10.17306/J.JARD.2017.00272.

5. Deckers, J., Cundall, S.H., Shomari, N.A. and Bassi, G., 2001. Cashew Crop Production in Tropical Africa. Brussels, Belgium: Directorate General for International Cooperation (DGIC), pp. 236-238.

6. Emengini., G. N., 2013. Recover of Cost of Electricity Supply In the Nigeria Power Sector. In: J. Jelilo and K.A. Bahago (eds). Agro-Allied Industry and its Relevance on Economic Performance: Evidence from Nigeria. Nile Journal of Business and Economics. 6(1): 25-32, http://dx.doi.org/10.20321/nilejbe.v3i6.93.

7. Essays UK, 2018. The Industrial Development Policies In Nigeria Economics Essay. Available through: https://www.ukessays.com/essays/economics/review-the-industrial-development-policies-innigeria-economics-essay.php?vref $=1$.

8. Jelilo, J. and Bahago, K.A., 2017. Agro-Allied Industry and its Relevance on Economic Performance: Evidence from Nigeria. Nile Journal of Business and Economics. 6(1): 2532.http://dx.doi.org/10.20321/nilejbe.v3i6.93.

9. National Planning Commission NEEDS, 2004. Federal Republic of Nigeria Abuja. In: D.C. Uzoigwe (ed). Economic Development In Nigeria through the Agricultural, Manufacturing And Mining Sectors: An Econometric Approach. PhD Dissertation: University Of Pretoria.

10. NPCS, 2000. Handbook on agro based industries.Niir Project Consultancy Services (p. 40-55).

11. Olomola, P.O., 2004. The FDI-Growth Hypothesis: A VAR Model for Nigeria. South African Journal of Economic and Management Sciences. 7(1): 181-193.

12. Oraka, E.O., Ocholi, A. and Ater, P.I., 2017. Social Impact of Agro-Allied Industries on the Rural Dwellers in Benue State, Nigeria. Journal of Agribusiness and Rural Development. 43(1): 157-162. http://dx.doi.org/10.17306/J.JARD.2017.00272.

13. Deakins, D. and Freel, M..S, 2009. Entrepreneurial activity, the economy and the importance of small firms. Entrepreneurship and small firms. McGraw-Hill Education.

14. Hisrich, R.D., 2011. Entrepreneurship. McGraw-Hill Education.

15. Mendy, C. and Kaira, D., 2015. Enhanced Value To Reverse The Long-Term Decline In Africa's Competitiveness. Agro-Cashew Processing For Economic Development. Available through: https://www.changemakers.com/sites/default/files/unilever_sustainable_living_young_entrepreneur_ award_2015_business_plan.pdf.

16. Azam-Ali, S.H. and Judge, E.C., 2006. Small-scale cashew nut processing. Food and Agriculture Organization (FAO). Available through: http://www.fao.org/ag/ags/agsi/Cashew/Cashew.htm.

17. Karim, A.J., 2011. The Significance Of Management Information Systems For Enhancing Strategic And Tactical Planning. Journal of Information Systems and Technology Management. 8(2): 459470. DOI: 10.4301/S1807-17752011000200011.

18. Sule, J.G., Abutu, T.Y. and Nafiu, A.T., 2019. Analysis of Entrepreneurial Potential and Financial Performance of Cashew Processors in Kogi State. Economic Insights - Trends and Challenges. 8(3): $11-22$. 
19. Oluwagbemiga, E., 2017. International Trade and Nigeria's mono-product oil-based Economy. A Study of the African Catfish Aquaculture Industry. Available through: https://www.grin.com/document/374054.

20. Varrella, S., 2021b. Contribution of agriculture to GDP in Nigeria 2019-2020. Available through: https:/www.statista.com/statistics/1193506/contribution-of-agriculture-to-gdp-in-nigeria/.

21. Varrella, S., 2021a. Contribution of oil sector to GDP in Nigeria 2018-2020. Available through: https:/www.statista.com/statistics/1165865/contribution-of-oil-sector-to-gdp-in-nigeria/.

22. PwC Nigeria, 2021. Assessing current market conditions and business growth prospects. Nigeria SME Survey. Available through: https:/www.pwc.com/ng/en/events/nigeria-sme-survey.html\#: :text $=$ In $\% 20$ Nigeria $\% 2$ C $\% 20$ SMEs $\% 20$ contribute $\% 2048$, businesses $\% 20$ and $\% 2084 \% 25 \% 20$ of $\% 20 \mathrm{empl}$ oyment.\&text $=$ With\%20a\%20total\%20number\%20of,terms\%20of\%20number\%20of\%20enterprises.

23. Onwualu, A.P., 2009. Developing Agricultural Raw Materials For Wealth Creation In Nigeria. $3^{\text {rd }}$ Forum of The Laureates of the Nigerian National Order of Merit (Nnom), Abuja, Merit House Complex.

Appendix 1. Heteroskedasticy test

\begin{tabular}{lll}
\hline \hline F-statistic & 1.734007 Prob. F $(1,8)$ & 0.2244 \\
Obs*R-squared & 1.781391 Prob. Chi-Square(1) & 0.1820 \\
Scaled explained SS & 1.535273 Prob. Chi-Square(1) & 0.2153 \\
\hline \hline
\end{tabular}

Source: Authors' computation

Test Equation:

Dependent Variable: RESID ${ }^{\wedge} 2$

Method: Least Squares

Date: 03/29/21 Time: 09:56

Sample: 20102019

Included observations: 10

\begin{tabular}{|c|c|c|c|}
\hline Variable & Coefficient & Std. Error & t-Statistic Prob. \\
\hline $\mathrm{C}$ & $-2.18 \mathrm{E}+08$ & $5.31 \mathrm{E}+08$ & -0.4108090 .6920 \\
\hline CTAS & 1324301. & 1005684. & 1.3168170 .2244 \\
\hline R-squared & 0.178139 & Mean dependent var & $\begin{array}{r}4.18 \mathrm{E} \\
\quad+08\end{array}$ \\
\hline Adjusted R-squared & 0.075406 & S.D. dependent var & $\begin{array}{r}7.24 \mathrm{E} \\
+08\end{array}$ \\
\hline S.E. of regression & $6.96 \mathrm{E}+08$ & Akaike info criterion & $\begin{array}{r}43.736 \\
30\end{array}$ \\
\hline Sum squared resid & $3.87 \mathrm{E}+18$ & Schwarz criterion & $\begin{array}{r}43.796 \\
82\end{array}$ \\
\hline Log likelihood & -216.6815 & Hannan-Quinn criter. & $\begin{array}{r}43.669 \\
91\end{array}$ \\
\hline F-statistic & 1.734007 & Durbin-Watson stat & $\begin{array}{r}2.0546 \\
69\end{array}$ \\
\hline Prob(F-statistic) & 0.224369 & & \\
\hline
\end{tabular}


Appendix 2. Multicollinearity test

\begin{tabular}{cccc}
\hline \hline & Coefficient & Uncentered & Centered \\
Variable & Variance & VIF & VIF \\
C & & & \\
CTAS & $3.05 \mathrm{E}+08$ & 5.825446 & $\mathrm{NA}$ \\
\hline \hline
\end{tabular}

Source: Authors' computation

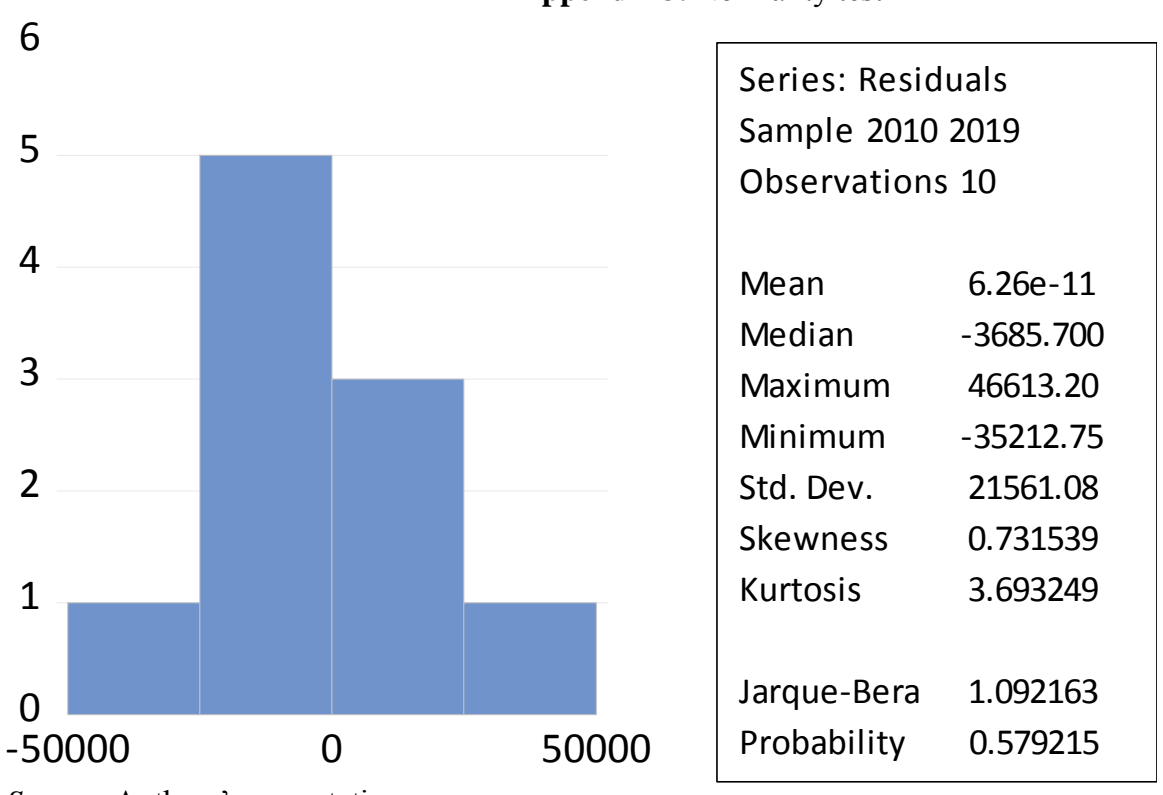

Appendix 3. Normality test

Source: Authors' computation 